\title{
ЕТНОДЕМОГРАФСКИТЕ ПРОМЕНИ ВО БРЕГАЛНИЧКИОТ (ШТИПСКИОТ) ОКРУГ ВО ПЕРИОДОТ 1913-1918 Г. ${ }^{1}$
}

\section{Кратка содржина}

Во текот на Втората балканска војна, српската војска ја заземала долината на реката Брегалница. По завриувањето на воените дејствија и потпишувањето на Букурешкиот договор во 1913 година бил формиран Штипскиот округ. Административниот иентар се наоѓал во градот Штип. Во јануари 1914 година Штипскиот округ бил преименуван во Брегалнички. Според офииијалните пописнини податочи во 1913 година во Брегалничкиот округ живееле 101.442 жители, ито претставува значајно намалување на вкупниот број на население во споредба со периодот непосредно пред балканските војни. Главната причина за намалувањето на бројот на населението било иселувањето на турското, односно муслиманското население после 1912 година. Есента 1915 година во вардарска Македонија била воспоставена бугарска управа. Министерството за внатрешни работи и народно здравје на Бугарија во 1917 година објавило брошура со наслов „Список на населените места во Македонија, Моравско и Одринско“. Според овие податочи кон итипскиот округ биле придодадени кавадарската и неготинската околија. Вкупното население на округот во 1917 година изнесувала 138.430 жители. Со чел за подобра споредба со податоците од претходните години доколку го одземеме бројот на жителите од споменатите кавадарска и неготинска околија вкупно 36.204 жители, во штипскиот округ живееле 102.228 жители. По воспоставувањето на власта на Кралството на СХС, во 1921 година бил спроведен првиот попис на населението. Според овие податочи во брегалничкиот округ кој ги задржал границите од 1913 година, живееле 104.347 жители. Објавените податочи од пописот во 1921 година со својата деталност помагаат при споредбеното анализирање на структурата на населението на просторот на Македонија кој бил под власт на КСХС во однос на периодот од последната деченија од османското владеење, како и во време на балканските и Првата светска војна.

Клучни зборови: ШТИПСКИ (БРЕГАЛНИЧКИ) ОКРУГ; ЕТНО-ДЕМОГРАФСКИ ПРОМЕНИ; ПОПИСИ НА НАСЕЛЕНИЕ

Во текот на Втората балканска војна во српско - бугарскиот судир, српската војска воспоставила контрола врз долината на реката Брегалнища. По завршувањето на воените дејствија на овој простор во јули 1913 година бил формиран

\footnotetext{
${ }^{1}$ Трудот претставува проширена верзија на презентираното соопштение на Научниот собир „Македонија и Македонците во Првата светска војна“ одржан во МАНУ на 11.12.2014.
} 
Штипскиот округ. Административниот центар се наоѓал во градот Штип. ${ }^{2}$ Округот бил поделен на шест околии: Штипска, Кочанска, Малешевска, Радовишка, Светиниколска и Царевоселска. Светиниколската околија со првата административна поделба што ја извршила српската власт во октомври 1912 година припаѓала на Кумановскиот округ, а во јули 1913 година била приклучена кон Штипскиот округ. Со поделба на Малешевската околија, веројатно во декември 1913 година била формирана и Царевоселската околија, со што биле оформени границите на Штипскиот округ. ${ }^{3}$

До 1912 година територијата на која српските власти ќе го основаат Штипскиот округ била дел од Скопскиот санџак, односно дел од Косовскиот вилает. ${ }^{4}$ Посочената територија до 1912 година административно била поделена во четири кази: Штипска во чиј состав се наоѓала нахијата Бериќетли со седиште во Свети Николе (Клисели), Радовишката, Кочанската и Пехчевската каза (каза Османие) со седиште во Пехчево, која била оформена со соединување на нахите Малешево и Пијанец во 1891/92, за што било издадено посебно султанско ираде. ${ }^{5}$ Сумирајќ ги податоците за бројот и структурата на населението во четирите споменати кази според Салнамето (Годишникот) од 1896/97 (1314) година, живееле вкупно 109.738 жители од кои 58.442, (53.2\%) христијани и 50.487, (46\%) муслимани.

Официјалните османски статистички податоци се разликуваат од проценката на бугарскиот етнограф Васил К`нчов за бројот и структурата на населението во споменатите четири кази во последните години на XIX век. На овој простор според статистиката на В. К`нчов живееле 135.410 жители. ${ }^{6}$ Според верската при-

${ }^{2}$ Српски извори за историјата на македонскиот народ 1912-1914, Избор, редакщија и коментар д-р Глигор Тодоровски, Скопје, 1979, 257-258.

${ }^{3}$ Милош Јагодић, Нови крајеви Србије (1912-1915), Београд, 2013, 108; Српски извори за историјата на македонскиот народ 1912-1914...,54; Милош Јагодић, „Административна подела нових крајева Србије 1912 - 1914“, Косовско-метохиски зборник 5, Београд, 2013, 157.

${ }^{4}$ Салнаме на Вилаетот Косово, превод од Османско - турски јазик, Скопје, 2012, 5-6; Драги Ѓоргиев, Административната структура на Солунскиот, Битолскиот и Косовскиот вилает во Втората половона на XIX век, Прилози на МАНУ, Одделение за општествени науки, XLI 1-2, Скопје, 2010, 170 - 171; Милош Јагодић, Српско-албански односи у Косовском вилајеmу 1878-1912, Београд, 2010.

${ }^{5}$ Според официјалната османска статистика кон крајот на XIX век во Штипската каза вклучувајќк ја и нахијата Бериќетли (подоцнежната Светиниколска околија) живееле: 41.675 жители од кои 23.370 муслимани, 17.496 христијани, 505 Евреи и 304 Роми и други. Вкупниот број на жители на Радовишката каза изнесувал 18.482 од кои 10.685 муслимани и 7 . 797 христијани. Во Кочанската каза вкупно живееле 29.029 жители од кои 11.390 муслимани и 17.635 христијани и во Пехчевската каза (каза Османие) живееле 20.552 жители од кои 5.042 муслимани и 15.510 христијани. (Салнаме на Вилаетот Косово..., 198,216, 231, 235). Во вкупниот број на жителите на Штипската каза во Салнамето од 1896/97 година наместо 41.675 стои 31.675 жители.

6 Васил Кънчов, Македония етнография и статистика, второ фототипно издание, София, 1996, 225-235. Според споменатата статистика на К`нчов етничката структура на на- 
падност 74.042, (54.7\%) од населението било православно, 60.548, (44.7\%) биле со муслиманска вероисповед и 800 жители, населени во градот Штип биле Евреи. Најголемиот дел од православното македонско население припаѓал на Бугарската егзархија, додека еден помал дел бил под јурисдикција на Цариградската патријаршија, односно се наоѓале под јурисдикција на скопскиот патријаршиски митрополит.

Во 1903 година, османската власт по смирувањето на состојбите спровела попис на населението во Вилаетот. Резултатите од одвој попис биле користени и при спроведувањето на изборите за османскиот парламент во 1908 година. ${ }^{8}$ Според овие податоци во споменатите четири кази живееле вкупно 124.850 жители. Податоците од пописот спроведен во 1903 година покажуваат дека дошло до зголемување на вкупниот број на населението, особено видливо е зголемувањето на бројот на муслиманското население. Бројот на Муслиманите и Христијаните бил речиси изедначен. Вкупниот број на муслиманско население бил 62.340, (49.9\%), додека бројот на христијанското население изнесувал $62.114,(49.8 \%)$. Во структурата на македонското православно население во мнозинство било егзархиското население со 60.456 жители, додека како припадници на Цариградската патријаршија биле евидентирани 1.658 жители. ${ }^{9}$ Приближно исти податоци за бројот и структурата на населението соопштува и Кристаќ Прифти според кого во споме-

селението била следна: „72.022, (53.2\%) Бугари; 48.981, (36,2\%) Турци; 2.917, (2.1\%) Цигани; 2.020, (1.5\%) Власи.“ Останатите етнички групи биле застапени минимално.

${ }^{7}$ Според статистиката на секретарот на Егзархијата Димитар Мишев на почетокот на XX век верската структура на христијанското население била следна: „Во Штипската каза живееле вкупно 24.328 Бугари егзархисти. Во Радовишката каза живееле 10.920 Бугари егзархисти и 320 протестанти. Во Пехчевската каза живееле 18. 688 Бугари егзархисти, 1.200 Бугари патријаршисти и 12 Власи. Во Кочанската каза живееле 23.592 Бугари егзархисти, 1. 040 Бугари патријаршисти, 402 Власи и 228 православни Цигани.“ D.M Brancoff, La Macédoine et sa Population Chrétiennen, Paris, 1905, 134 - 141.

${ }^{8}$ Милош Јагодић, Српско-албански односи у Косовском вилајету..., 257.

${ }^{9}$ Ibidem, 256 Структурата на населението по кази била следна: Во Штипската каза вкупно биле евидентирани 45. 054 жители, од кои 27.081, (60.1\%) муслимани, 17.973 жители биле православни, односно припадници на Бугарската егзархија. Во Радовишката каза вкупно биле евидентирани 20.258 жители од кои 11.773 (58.1\%) муслимани и 8.485 (41.9\%) православни, припадници на Бугарската егзархија. Во Кочанската каза вкупно биле евидентирани 31.418 жители од кои 12.610 (40.1\%) муслимани, 17.789 (56.6\%) православни припадници на Бугарската егзархија и 1.019 (3.2\%) православни, припадници на Цариградската патријаршија. Во Пехчевската каза (Османие) вкупно биле евидентирани 28.324 жители од кои 10.876 (38.4\%) муслимани, 16.809 (59.3\%) православни припадници на Бугарската егзархија и 639 (2.2\%) православни, припадници на Цариградската патријаршија. Според извештајот на скопскиот патријаршиски митрополит Фирмилијан (Дражиќ) од март 1902 година: „во Кочанската каза имало 151 српска патријаршиска куќа во градот Кочани и пет околни села и 211 српски патријаршиски семејства во Пехчевската каза, во Пехчаво, Берово, Ратево и Смојмирово.“ (Државен архив на Република Македонија 1.17.1.13/101 - 105). 
натите четири османски кази (Штипска, Кочанска, Радовишка и Пехчевска) на почетокот на XX век живееле 123.666 жители. ${ }^{10}$

Непосредно пред почетокот на балканските војни на просторот на подоцнежниот Штипски округ, според проценката на Јордан Иванов, живееле 135.065 жители. ${ }^{11}$ Според посочениве статистички податоци во првата деценија на XX век турското население претставувало мнозинство во тогашните Штипска и Радовишка каза, додека македонското егзархиско и патријаршиско население претставувало мнозински дел од населението на Пехчевската и Кочанската каза. Во Пехчевската каза покрај турско живеело и исламизирано македонско население. ${ }^{12}$ Ваквата етничка слика после балканските војни ќе биде значително, а во некои предели коренито променета. Еден дел од турското, односно муслиманското население се повлекол заедно со турската војска уште есента 1912 година.

Првите официјални податоци за бројот на населението во „новите области“ на Србија се објавени во 1914 година, а се однесуваат на пописот на населението спроведен во текот на 1913 година. На почетокот на 1913 година Врховната команда на српската војска издала наредба за попис на населението во областите каде воспоставила власт во текот на Првата балканска војна. Полициските власти во текот на февруари и март го извршиле попишувањето на населението, опфаќајки го вкупниот број на населението, бројот на домаќинствата, односно куќите, вклучувајќи и напуштените, половата и националната структура и говорниот јазик на населението. Во областите кои потпаднале под српска власт по Втората балканска војна, наредбата за попишување на населението била издадена во октомври 1913 година. Министерот за внатрешни работи на Србија на трети октомври 1913 година наредил на територијата на Штипскиот округ да биде спроведен попис на населението. ${ }^{13}$

Податоците добиени од пописот се значајни за историско - демографските проучувања поради можноста за споредба со податоците од пред балканските војни. Во официјално објавените податоци не е набележана етничката, ниту верската припадност на населението, но во сочуваните архивски материјали може да

${ }^{10}$ Kristaq Prifti, Popullsia e Kosovës 1831 - 1912, Tiranë, 2014, 770 - 784. Според Прифти верската структурата на населението била следна: во Штипската каза живееле вкупно 45.016 жители, од кои 23.862 биле муслимани, 20.543 православни и помал број на Евреи и Роми. Во Радовишката каза живееле 20.856 жители од кои 11.773 муслимани, 8.632 православни и 451 Роми. Во Кочанската каза живееле вкупно 31.832 жители од кои 18.811 православни 12.356 муслинани како и помал број на пропадници на други заедници. Во Пехчевската каза (Османие) вкупно живееле 25.962 жители од кои 17.012 православни и 8.950 муслимани.

${ }^{11}$ Йордан Иванов, Бъгарите в Македония, София, 1915, СІІІ.

12 Архив на Македонската Академија на Науките и Уметностите (во понатамошниот текст Архив на МАНУ), ф. Бранислав Русиќ к-5, а.е 96; Јован Хаџи Васиљевић, Муслимани наше крви у Јужној Србији, Београд, 1924.

${ }^{13}$ Милош Јагодић, Нови крајеви Србије (1912-1915)...,115; истиот, „Административна подела нових крајева Србије 1912 - 1914“...,160. 
се најдат и овие податоци со што повеќе или помалку може да се добие претстава за етничката и верската структура во посочените области непосредно по завршувањето на Балканските војни. Пописните податоци не ја отсликуваат вистинската етничка слика на населението во Македонија. За прецизноста на податоците сомнеж искажува и Полицискиот инспектор при Врховната команда на српската војска Милорад Вујичиќ кој вели: „На распределбата кој е Србин, а кој Бугарин не е посветено големо внимание, бидејќ тие кои претходно се декларирале за Бугари сега самите се нарекуваат Срби, така што во тој поглед податоците не можат да се сметаат за точни бидејќи за Бугари се забележани само оние кои заради близината на бугарската граница биле под силно бугарско влијание.“" ${ }^{14}$ Официјално објавените статистички податоци даваат само сумарен податок за вкупното население во деловите од Македонија под српска власт. Според анализата на овие податоци на просторот на денешна Р. Македонија без Струмичко, живееле околу 890.000 жители. ${ }^{15}$ Од вкупниот број на населението 269.324 жители, односно $30.2 \%$ живееле во градските населби или како официјално биле евидентирани како вароши и варошищи.

Во јануари 1914 година Штипскиот округ бил преименуван во Брегалнички, додека претходно во ноември 1913 година светиниколската околија била преименувана во овчеполска. ${ }^{16}$ Според официјалните пописни податоци во 1913 година во Брегалничкиот округ живееле 101.442 жители, што претставува намалување на вкупниот број на население во споредба со периодот непосредно пред балканските војни. ${ }^{17}$ Една од причините за значителното намалување на вкупниот број на жители на округот е територијалното намалување на штипската околија, која завземала помала територија во однос на поранешната штипска каза. ${ }^{18}$

Сепак главната причина за намалувањето на бројот на населението било иселувањето на дел од турското, односно муслиманското население после 1912 година и иселувањето на македонското егзархиско население (во помал број во однос на турското население). За време на одржувањето на пописот во десет села воопшто немало жители, што било последица на нивното раселување. ${ }^{19}$ Во општото намалување на бројот на населението во округот карактеристично е намалувањето на градското население. Штип според официјалните податоци во 1913 година броел 15.314 жители, ${ }^{20}$ што претставува намалување за $1 / 4$ во однос на населени-

${ }^{14}$ Српски извори за историјата на македонскиот народ..., 102.

${ }^{15}$ Мил. Ант. Вујичић, Речник места у Ослобођеној области Старе Србије. По службеним податиима, Београд, 1914, 2 - 3.

${ }^{16}$ Милош Јагодић, Нови крајеви Србије (1912-1915)...,108-110.

${ }^{17}$ Мил. Ант. Вујичић, Речник места у Ослобођеној области Старе Србије...,27.

${ }^{18}$ Еден дел од селата кои до 1912 година ѝ припаѓале на Штипската каза со новата административна поделба биле припоени кон Неготинската околија, главно во новоформираните општини Драгоево, Уланщи и Џидимирци.

${ }^{19}$ Од раселениете села четири биле во Овчеполската, а шест во Штипската околија.

${ }^{20}$ Мил. Ант. Вујовић, Речник места у Ослобођеној области Старе Србије...,27. 
ето што Штип го имал пред Балканските војни. ${ }^{21}$ Според деталниот извештај на окружниот началник повеќе села во сите околии во текот на воените дејствија во балканските војни биле целосно или делумно уништени. Началникот Грковиќ во извештајот наведува дека: „во Штип, Кочани и Радовиш многу куќи се срушени, особено во Штип - цели маала.“22 И останатите градчиња, варошици според официјалната терминологија, бележат пад во бројот на жителите во однос на периодот од пред балканските војни. Според споменатиот детален извештај за состојбата во Штипскиот округ, во Кочани живееле 3.794 жители, „во мнозинство муслимани, значително помалку Срби, а уште помалку Куцовласи и Цигани.“23 За разлика од извештајот, во официјалната статистика Кочани е евидентиран со 5.420 жители. ${ }^{24}$ Несомнено, во Кочани дошло до пад во бројот на населението, бидејќи кон крајот на XIX век во градот живееле 5.950 жители. ${ }^{25}$ Во 1913 година до значително намалување на населението дошло и во Радовиш, каде биле регистрирани 4.045 жители, „во мнозинстово муслимани, а помалку Срби.“26 Во однос на последната деценија од турското владеење градот во балканските војни изгубил над една третина од населението. ${ }^{27}$ Најголем пад во бројот на населението бележи Пехчево, административниот центар на казата Османие. Според проценките на J. Иванов, непосредно пред балканските војни во Пехчево живееле 5.680 жители. ${ }^{28}$ Иселувањето на муслиманското население од градчето започнало за време на Првата балканска војна, дури пред влегувањето на бугарската војска во Пехчево. Тие се повлекле заедно со турската војска. ${ }^{29}$ Во есента 1913 година Пехчево брое-

${ }^{21}$ Според извештајот на началникот на Брегалничкиот округ Љ. Грковиќ во градот Штип живееле 12.342 жители, додека подолу во извештајот наведува друга бројка „од 13.314 жители од кои 7.211 Срби, 5.590 Муслимани и 530 мојсиевци,.. (Српски извори за историјата на македонскиот народ...,263, 270). Глигор Тодоровски, Македонија по распарчувањето 1912/13 - 1915 опитествено - политички, економски и просветни прилики во Вардарскиот дел на Македонија, Скопје, 1994, 89 - 92.

${ }^{22}$ Ibidem, 307.

${ }^{23}$ Ibid, 270.

${ }^{24}$ Мил. Ант. Вујичић, Речник места у Ослобођеној области Старе Србије...,30.

${ }^{25}$ Васил Кънчов, Македония етнография и статистика...,225. Кристаќ Прифти наведува дека во периодот 1905/07 во градот Кочани живееле 4.304 жители, релативно мнозинство претставувале Турците со $45 \%$ од вкупното население. (Kristaq Prifti, Popullsia e Kosovës $1831-1912 \ldots, 918)$.

${ }^{26}$ Српски извори за историјата на македонскиот народ...,270; Мил. Ант. Вујичић, Речник места у Ослобођеној области Старе Србије..,,34.

${ }^{27}$ Според проценката на К'нчов кон крајот на XIX век во Радовиш живееле 6.230 жители, од кои 2/3 Турци. (Васил Кънчов, Македония етнография и статистика...,233). Според Прифти во првата деценија на XX во Радовиш живееле 4.100 жители од кои $65 \%$ Турци. (Kristaq Prifti, Popullsia e Kosovës 1831 - 1912...,915).

${ }^{28}$ Йордан Иванов, Бъгарите в Македония..., 7. Прифти наведува бројка од 3.865 жители од кои 3.200 Турци. (Kristaq Prifti, Popullsia e Kosovës 1831 - 1912...,921).

${ }_{29}^{29}$ Даринка Пачемска Петреска, Малешевијата низ историјата, 1912-1945, Берово, 2003, 32; Српски извори за историјата на македонскиот народ...,270. 
ло само 694 жители, ${ }^{30}$ со што приматот на администартивен центар го презел Берово.

За разлика од наведените градови, односно административни центри, во Свети Николе и Царево Село, кои биле седишта на Овчеполската и Царевоселската околија бројот на населението во споредба со периодот пред Балканските војни, значајно не се намалил, односно стагнирал. Во Свети Николе пролетта 1913 година живееле 1.942 жители. ${ }^{31}$ Во Царево Село есента 1913 година живееле 1.701 жители, што во однос на проценките од крајот на XIX век претставувало сосема минимално зголемување на бројот на населението. ${ }^{32}$

Српската управна и административна власт фукнционирала во Брегалничкиот округ до средината на октомври 1915 година. На 14 октомври Бугарија влегла во војната на страната на Централните сили и уште истиот ден бугарските војски воспоставиле контрола во Берово, Пехчево и Царево Село. На 17 октомври бугарските војски ги заземале Виница и Кочани, а на 18 октомври - Штип, про-

${ }^{30}$ Мил. Ант. Вујичић, Речник места у Ослобођеној области Старе Србије...,31. Во 1913 година било разурнато селото Безгаштево, а неговите жители главно мухаџири се иселиле во М. Азија. (Димитар Г. Гаджанов, Мюсюманското население в новоосвободените земи, Научна експедичија Македонија и Поморавието, 1916 г. съст. Петьр Хр. Петров, София, 1993, 141). Во споменатото село после Берлинскиот конгрес биле населени мухаџири од Херцеговина, Бугарија и Србија. (Seobe kao sudbina, Priredio: Ismet Kočan, Skoplje, 2011, 132, 153).

${ }^{31}$ Мил. Ант. Вујичић, Речник места у Ослобођеној области Старе Србије...,32. Окружниот началник Љ. Грковиќ во извештајот од јануари 1914 година наведува дека: „во Свети Николе живеле 1.892, пола Срби, пола муслимани.“ (Српски извори за историјата на македонскиот народ...,271). Српската власт на териториите што ги освоила во текот на Првата балканска војна спровела попис на населението во текот на февруари и март 1913 година. Во овој период Светиниколската околија била под српска власт и според официјалните српски податоци од спроведениот попис во оваа околија живееле вкупно 15.275 жители, од кои според бројот на куќкте: “1.270 куќи или 47.8\% биле бугарски, а 1.336 куќи или 51.3\% биле турски.” (Милош Јагодић, Нови крајеви Србије (1912-1915)...,118).

${ }^{32}$ Според К'нчов на крајот на ХIX век во Царево Село живеле: „520 православни Бугари, 575 муслимански Бугари, 425 Турци и 90 Цигани.“ (Васил Кънчов, Македония етнография и статистика...,228). Споменатиот началник на Брегалничкиот округ за Царево Село вели: „Има 1.638 жители, во мнозинство муслимани, а во значително помал број Срби.“ (Српски извори за историјата на македонскиот народ...,271). Според истражувањата на проф. Бранислав Русиќ во периодот на балканските и Првата светска војна еден дел од муслиманското население се иселил во М Азија, но процесот на иселување бил помал во однос на Кочанската или Овчеполската котлина. Во помал број се иселувало и македонското населние во Бугарија. Најголемо иселување имало од селото Цр(в)ник, во 1913 година околу 100 семејства се иселиле во М.Азија, иселувањето од ова село продолжило и во периодот по 1918 година. Иселувања на муслиманското население имало и од селата Вирче, Град, Звегор, Габрово, како и од Царево Село од каде после 1912 година и во периодот меѓу двете светски војни се иселиле околу 10 муслимански семејства. Од наведените села во Пијанец муслиманското население најмногу се населувало во градовите Маниса, Ески Шехир и Измир. Од селата Панчарево, Стар Истевник, Разловци, Тодоровци и др. по 1918 година по неколку семејства се иселиле во Бугарија. (Архив на МАНУ ф. Бранислав Русик, а.е 96/I, 10-230). 
должувајќи кон Велес. ${ }^{33}$ Брегалничкиот округ, сега именуван како Штипски бил дел од Македонска воено-инспекциска област. Бугарските власти во административно територијален аспект во округот на почетокот од својата управа не направиле поголеми промени, така што Штипскиот округ и понатаму останал поделен на шест околии (Штипска, Беровска, Царевоселска, Светиниколска, Кочанска и Радовишка). Бугарската администрација во некои околии направила помали измени во бројот на општините и нивната големина. ${ }^{34}$ Заради воените услови и краткиот временски период бугарските власти не извршиле целосен и сеопфатен попис на населението, заради што и податоците за демографската структура на населението се разликуваат и не се сосема прецизни во зависност од изворот кој го користеле. Како пример за Штипскиот округ ке ги наведеме податоците на Стефан Димитров, началник во главната дирекција за статистика и на Димитар Г. Гаџанов, лектор по турски јазик на Софискиот универзитет, ${ }^{35}$ кои патувале и собирале податоци низ Македонија и Поморавјето во летото 1916 година. Според податоците на С. Димитров, во Штипскиот округ во периодот јули/август 1916 година живееле помалку од 100.000 жители. Тој констатира дека имало големо иселување особено на муслиманското население за време и по балканските војни. Во Кочани на пример пред балканските војни имало околу 1.600 куќи, додека во 1916 год само околу 850 куќи биле населени. Слична состојба од етнодемографски аспект била констатирана и за Кочанската околија, од каде според Димитров во перидот 1912 - 1916 година се иселило повеќе од половина од турското население. ${ }^{36}$ Според извештајот на Д. Гаџанов, во шесте околии на Штипскиот округ во 1916 година живееле вкупно 101.060 жители. Во однос на етничката стуктура на населението според овие податоци дошло до определени промени во однос на периодот пред 1912 година. Во округот во 1916 година живееле: „70.854 (70.1\%), Бугари; 22.385 (22.2\%); Турци, 5.652 (5.6\%) Помаци; 1.626 (1.6\%) Цигани; 400 (0.4\%) Евреи и 139 останати.““37

Споредувајќи ги посочените податоци со проценките на населението правени непосредно пред балканските војни, од страна на бугарските истражувачи, видливо е значителното намалување на бројот на турското население во округот. Пред балканските војни турското население претставувало мнозинство во Штип-

\footnotetext{
${ }^{33}$ Иван Петров, Войната в Македония (1915 - 1918), София, 2008, 24.

${ }^{34}$ Стефан Димитров, Северозападна Македония (Народностопанска анкета - 1916), Научна експедиция в Македония и Поморавието, 1916 г. съст. Петър Хр. Петров, София, 1993, 81; Крсте Битовски, Положбата на Вардарска Македонија за време на бугарската окупачија 1915 - 1918, ГИНИ, IV/1 - 2, Скопје, 1960, 48: Никола Едровски, „Штип во војните (1912 - 1918 г.),, Македонија во војните 1912 - 1918, Прилози од Научниот собир одржан во МАНУ на 16 и 17 ноември 1988 година, Скопје, 1991, 353.

35 Димитьр Г Гаджанов, Мюсюманското население вновоосвободените земи, Научна експедиция в Македония и Поморавието, 1916 г. съст. Петър Хр. Петров, София, 1993.

${ }^{36}$ Стефан Димитров, Северозападна Македония (Народностопанска анкета - 1916)...,82.

${ }^{37}$ Димитьр Г Гаджанов, Мюсюманското население в новоосвободените земи...,279- 281.
} 
ската и Радовишката каза. ${ }^{38}$ Во 1916 година Турците според наведените податоци претставувале $27 \%$ од населението на Штипската околија и $41.7 \%$ од населението на Радовишката каза. ${ }^{39}$ Во посочениве статистички податоци бројот на турското население е прикажан помал во однос на реалниот, особено е намален бројот на Турците во Светиниколската ${ }^{40}$ и Радовишката околија. И покрај видливите грешки и непрецизности во статистичките податоци, во однос на 1912 година, навистина бројот на турското население бил речиси преполовен. Во статистичките податоци „недостасува“ влашкото население кое го има во сите статистики пред и после 1916 година. ${ }^{41}$ Во статистички податоци од 1916 година целото муслиманско население од Беровската и Царевоселската околија е евидентирано како исламизирано, односно помачко население. ${ }^{42}$

Покрај непрецизностите во податоците за бројот на турското население во округот, несомнено неговиот број се намалил како последица на постојаните иселувања кои започнале со балканските војни. Ќе наведеме повеќе примери од Кочанско и Овче Поле. Еден дел од турското население се повлекло со турската војска уште во 1912 година. Некои дотогаш големи и богати села останале празни. Најнапред се иселувале Турците кои биле дел од дотогашниот управен апарат, агите, беговите, односно покрупните земјосопственици. Од Кочанската околија во 1912 година турското население целосно се иселило од селата Долни Подлог, Грдовци, Оризари и Калиманци. Селото Калиманци непосредно пред балканските војни броело околу 150 куќи. Во него живеело исламизирано македонско население, заедно со турски колонисти (мухаџири), населени во селото 1878 година од

${ }^{38}$ Васил Кънчов, Македония етнография и статистика...,230-235; Йордан Иванов, Бъгарите в Македония, CIII; Милош Јагодић, Српско-албански односи у Косовском вилајету, Београд, 2009, 262.

39 Димитьр Г Гаджанов, Мюсюманското население в новоосвободените земи...,279 - 281.

${ }^{40}$ Во Светониколската околија според податоците од пописот одржан пролетта 1913 година, 51.3\% од домаќинствата биле турски. (Милош Јагодић, Нови крајеви Србије (19121915)...,118).

${ }^{41}$ Влашкото население до балканските војни во источните делови на Македонија биле номадски сточари. Во лето престојувале на планините Осогово, Плачковица, Огражден, Беласица, а во зима стадата ги пренесувале во Овче Поле, во Кочанската котлина, во долините на Лакавица, или Злетовска река, а некои ги носеле стадата и во Солунско. К`нчов забележува дека во Кочанската каза кон крајот на XIX век имало 2.020 Власи. (Васил Кънчов, Македония етнография и статистика...,227).

42 Димитьр Г Гаджанов, Мюсюманското население в новоосвободените земи...,279 - 281. Во зависност од изворот намената на пишувањето и интерпретацијата, муслиманското население во Пехчевската каза, било различно евидентирано. К'нчов проценува дека кон крајот на XIX век во казата живееле: „8.605 Бугари мухамедани и 425 Турци.“ (Васил Кънчов, Македония етнография и статистика...,229). Според Иванов во 1912 година во казата живееле 4.700 Турци (Йордан Иванов, Бъгарите в Македония, СIII), што значи дел од муслиманското население го евидентирал како бугарско. Кристаќ Прифти спредувајќи повеќе извори наведува дека во казата во првата деценија на XX век живееле 3.500 Помаци. (Kristaq Prifti, Popullsia e Kosovës 1831 - 1912...,919). 
Бугарија. Сите муслимански жители на селото се повлекле со османската војска кон Велес и Солун. Дел од жителите по завршувањето на воените дејства се вратиле, но бидејќи селото било запалено се населиле во околните села. Од селото Оризари заедно со османската војска се повлекло и турското население, околу деведесет домаќинства. Од Истибања во 1912 година од вкупно двесте турски домаќинства во Мала Азија се иселиле 170, како и од селото Теранци од каде во 1912 година од вкупно 180 турски домаќинства во Мала Азија се иселиле околу 30. Најголемиот дел од турското население од селото се иселил во дваесетите години. Од селото Долни Подлог заедно со османската војска се иселиле 80 турски домаќинства, само 8 се вратиле и се населиле во Кочани и Облешево. Од селото Грдовци сите турски жители (околу 30 домаќинства) за време на балканските војни се иселиле во Мала Азија. Нивните куќи биле запалени. ${ }^{43}$

Турското население заедно со османската војска се повлекло и од селата Орел, Мустафино и Ерџелија во Овче Поле. Од селото Мало Црнилиште во 1912 година се иселило сето турско население. Од селото Орел во текот на Првата балканска војна се иселиле сите 60 турски домаќинства, како и од селото Мустафино од каде заедно со османската војска во 1912 година се повлекло сето турско население, околу 60 домаќинства. Од соседното село Ерџелија исто така се иселило сето турско население. ${ }^{44}$ Процесот на иселување на турското население за време на балканските војни го опфатил целиот слив на реката Брегалница, овој миграциски процес продолжил и за време на Првата светска војна, како и после 1918 година. ${ }^{45}$

Министерството за внатрешни работи и народно здравје на Бугарија во 1917 година објавило брошура со наслов „Список на населените места во Македонија, Моравско и Одринско“. Во воведот на публикацијата се наведува дека пребројувањето, односно пописот на населението не бил извршен врз основа на статистички методи, туку пребројувањето го вршеле административните власти. ${ }^{46}$ Според овие податоци кон Штипскиот округ биле придодадени Кавадаречката и Неготинската околија. Вкупниот број на населението во округот во 1917 година

43 Архив на МАНУ ф. Бранислав Русиќ, а.е 96/I, 230; Јован. Ф Трифуноски, Кочанска котлина, сеоска насеља и становништво, Скопје, 1970, 49, 79, 100-107, 128, 145.

44 Jovan F. Trifunoski, Ovčepoljska kotlina, Zbornik za narodni život I običaje, knjiga 42, Zagreb, $1964,643,705,731,752,755$.

45 Турското население за време на балканските војни се иселило во Мала Азија и од селата Софилари, Бекирлија и други. Ј. Трифуноски, В. Нетков, „Денешни села и население во долниот слив на Брегалница“, Зборник на Штипскиот народен музеј III 1962-1963, Штип, 1964, 39-54.

${ }^{46}$ Списъкъ на населените места въ Македония, Моравско и Одринско, Државна печатница, София, 1917, 2. Бугарските власти помеѓу 1916 и 1918 година администартивно ги дополнувале и ревидирале податоците за бројот и структурата на населението во македонската воено-инспекциска област. (проф. Ив. Странски, Гъстота на населението въ Македонската военно - инспекционна област през 1916 г., Македонски Прегледъ, година II, кн. 2, София, $1926,77)$. Штипскиот округ според информациите на „Македонското областно агрономство“ по укинувањето на Кавадеречкиот округ кој бил припоен кон Штипскиот имал 6.776 км $^{2}$ и бил најретко населена област во Македонија со 20 жители на км ${ }^{2}$. 
изнесувал 138.430 жители. Заради подобра споредба со податоците од претходните години, доколку го одземеме бројот на жителите од споменатите Кавадаречка и Неготинска околија вкупно - 36.204 жители, во Штипскиот округ живееле 102.228 жители. Во однос на административната поделба на српските власти од 1914 година, бугарските власти во текот на Првата светска војна направиле одредени помали промени од административно-територијален аспект. Во 1914 година Брегалничкиот округ се состоел од 6 околии, 41 општина и 262 населени места. ${ }^{47}$ Во 1917 година округот бил поделен на 8 околии, 76 општини и 379 населени места. Без Неготинската и Кавадаречката околија во округот имало 6 околии, 50 општини и 271 населено место. ${ }^{48}$

\begin{tabular}{|c|c|c|c|c|}
\hline Околија & 1913 & 1916 & 1917 & 1921 \\
\hline Кочанска & 27.295 & 23.486 & 23.386 & 25.711 \\
\hline Малешевска & 10.223 & 10.794 & 10.944 & 12.135 \\
\hline Овчеполска & 15.237 & 15.590 & 15.598 & 18.179 \\
\hline Радовишка & 16.361 & 16.391 & 16.291 & 16.440 \\
\hline Царевоселска & 11.500 & 12.289 & 13.505 & 14.019 \\
\hline Штипска & 20.828 & 22.510 & 22.522 & 17.863 \\
\hline Вкупно & 101.442 & 101.060 & 102.226 & 104.347 \\
\hline
\end{tabular}

Вкупен број на население во Брегалничкиот (Штипскиот округ) во периодот 1913 -1921 година ${ }^{49}$

По пробивот на Македонскиот фронт од страна на силите на Антантата, српската војска на 24 септември 1918 година го заземала Штип. На 26 септември српската војска влегла во Кочани, продолжувајќи кон Царево Село. ${ }^{50}$ Долината на реката Брегалница до крајот на септември 1918 година била под контрола на српската војска. По прогласувањето на Кралството на Србите Хрватите и Словенците во декември 1918 година, повторно бил воспоставен Брегалничкиот округ во границите од пред Првата светска војна.

Во 1921 година бил спроведен првиот попис на населението во Кралството на Србите Хрватите и Словенците. Според овие податоци во Брегалничкиот округ живееле 104.347 жители. ${ }^{51}$ Податоците од овој попис, се значаен статистички извор за проучување на структурата на населението како во Брегалничкиот округ,

\footnotetext{
${ }^{47}$ Мил. Ант. Вујичић, Речник места у Ослобођеној области Старе Србије...,29 - 36.

${ }^{48}$ Списъкъ на населените места въ Македония, Моравско и Одринско..., 111.

${ }^{49}$ Мил. Ант. Вујичић, Речник места у Ослобођеној области Старе Србије...,27; Димитьр Г Гаджанов, Мюсюманското население в новоосвободените земи.., 279 - 281; Списъкъ на населените места въ Македония, Моравско и Одринско..., 101 - 107; Дефинитивни резултати пописа становништва 1921 године, Сарајево, 1932, 92 - 95.

${ }^{50}$ Иван Петров, Войната в Македония (1915 - 1918)...,206 - 208.

${ }^{51}$ Дефинитивни резултати пописа становништва 1921 године..., 92.
} 
така и за Вардарскиот дел на Македонија, бидејќи тоа е првиот попис на населението направен на овој простор според меѓународно прифатена статистичка методологија. Податоците за бројот и структурата на населението од овој попис се значајни за споредба со податоците од првата деценија на XX век, како од од периодот $1912-1918$ год.

\section{Заклучок}

Бројот на населението во Вардарскиот дел на Македонија во периодот на балканските и Првата светска војна се намалил за повеќе од 100.000 жители, податок за кој сведочат податоците од пописите одржани на овој простор во 1913 и 1921 година. Анализирајќ ги податоците за етнодемографските движења на населението во Брегалничкиот (Штипскиот) округ во периодот на балканските и Првата светска војна се доаѓа до заклучок дека во округот бројот на населението во однос на периодот од пред балканските војни се намалува за околу дваесетина илјади жители. За разлика од некои други области во Македонија кои биле на фронтовата линија во Првата светска војна како Битолско, Мариовско, Дојранско, кои изгубиле значаен дел од своето население (Битола на пример има речиси 20.000 жители помалку во 1921 во однос на 1913 година), областите на Брегалничкиот округ не биле најдиректно изложени на воените дејствија, така што и бројот на населението не бележи пад како во споменатите области. Меѓутоа внатрешната демографска, односно етничка и верска структура била коренито променета. Процесот на иселување на турското, односно муслиманското население од 1912 година бил исклучително силен, заради што турското население го изгубило мнозинството во Радовишко и Штипско. Процесот на иселување на ова население продолжил и по 1918 година. Друг значаен демографски факт е изразитото намалување на бројот на населението во градовите, што повторно се должело на иселувањето на турското и останатото муслиманско население. Во сите градови, односно административни центри во округот дошло до значително намалување на населението. Штип на пример ќе го достигне бројот на жители од 1912 година дури во педесетите години на XX век. Слично било и во другите градови на округот. 


\section{Литература}

\section{Извори:}

Дефинитивни резултати пописа становништва 1921 године, Сарајево, 1932.

Салнаме на Вилаетот Косово, превод од Османско - турски јазик, Скопје, 2012.

Списъкъ на населените места въ Македония, Моравско и Одринско, Државна печатница, София, 1917.

Српски извори за историјата на македонскиот народ 1912-1914 Избор, редакција и коментар д-р Глигор Тодоровски, Скопје, 1979.

\section{Лuтература:}

Битовски Крсте, Положбата на Вардарска Македонија за време на бугарската окупација 1915 - 1918, ГИНИ, IV/1 - 2, Скопје, 1960.

Brancoff D. M, La Macédoine et sa Population Chrétiennen, Paris, 1905.

Вујовић Мил. Ант., Речник места у Ослобођеној области Старе Србије. По службеним податчима, Београд, 1914.

Гаджанов Г. Димитар, Мюсюманското население в новоосвободените земи, Научна експедичија Македонија и Поморавието, 1916 г. съст. Петър Хр. Петров, София, 1993.

Димитров Стефан, Северозападна Македония (Народностопанска анкета - 1916), Научна експедиция в Македония и Поморавието, 1916 г. съст. Петър Хр. Петров, София, 1993.

Ѓоргиев Драги, Административната структура на Солунскиот, Битолскиот и Косовскиот вилает во Втората половона на XIX век, Прилози на МАНУ, Одделение за општествени науки, XLI 1-2, Скопје, 2010.

Едровски Никола, Штип во војните (1912 - 1918 г.), Македонија во војните 1912 1918, Прилози од Научниот собир одржан во МАНУ на 16 и 17 ноември 1988 година, Скопје, 1991.

Иванов Йордан, Бъгарите в Македония, София, 1915.

Јагодић Милош, Српско-албански односи у Косовском вилајету 1878-1912, Београд, 2010; , Нови крајеви Србије (1912-1915), Београд, 2013; „Административна подела нових крајева Србије 1912 - 1914“, Косовско - метохиски зборник 5, Београд, 2013

Кънчов Васил, Македония етнография и статистика, второ фототипно издание, София, 1996.

Петров Иван, Войната в Македония (1915 - 1918), София, 2008.

Kristaq Prifti, Popullsia e Kosovës 1831 - 1912, Tiranë, 2014.

Петреска Пачемска Даринка, Малешевијата низ историјата, 1912-1945, Берово, 2003.

Seobe kao sudbina, Priredio: Ismet Kočan, Skoplje, 2011. 
Странски Ив., Гъстота на населението въ Македонската военно - инспекционна област през 1916 г., Македонски Прегледъ, година II, кн. 2, София, 1926.

Тодоровски Глигор, Македонија по распарчувањето 1912/13 - 1915 општествено - политички, економски и просветни прилики во Вардарскиот дел на Македонија, Скопје, 1994.

Трифуноски Ф. Јован, Кочанска котлина, сеоска насеља и становништво, Скопје, 1970; Jovan F. Trifunoski, Ovčepoljska kotlina, Zbornik za narodni život I običaje, knjiga 42, Zagreb, 1964; Ј. Трифуноски, В. Нетков, Денешни села и население во долниот слив на Брегалница, Зборник на Штипскиот народен музеј III 1962-1963, Штип, 1964.

Хаџи Васиљевић Јован, Муслимани наме крви у Јужној Србији, Београд, 1924. 
Borče ILIEVSKI

\section{ETHNO-DEMOGRAPHIC CHANGES IN BREGALNICA (ŠTIP) DISTRICT IN THE PERIOD 1913-1918}

\section{Summary}

During the second Balkan war, Serbian military invaded the valley of river Bregalnica. After the military actions ended and the Bucharest agreement was signed in 1913, the Stip district was formed. The administrative center was located in the city of Stip. The district was composed of six provinces: Štip, Kočani, Maleševo, Radoviš, Sv.Nikole and Carevo Selo area. Up until 1912 the territory where Serbian authorities will form the Stip district was part of the Skopje sanxak, precisely part of the Kosovo vilajet. In January 1914 the Stip district was renamed into Bregalnica district. According to the official census data in 1913 there were 101.442 residents living in Bregalnica district, which is a significantly decreased number of the total population compared to the period right before the Balkan wars. The main reason for this decrease of population was the emigration of the Turkish, the Muslim population after 1912. The fall of 1915 there was Bulgarian administration established in Vardar Macedonia. The Ministry of Interior and people's health of Bulgaria in 1917 published a brochure with the title "List of populated places in Macedonia, Morava ad Odrin area". According these data to the Stip district also added were the Kavadarci and Negotino provinces. The total population of the district in 1917 was 138.430 residents. In order to better compare the data from the previous years, if we take out the number of residents in the mentioned Kavadarci and Negotino district, which is 36.204 habitants, in the Stip district there were 102.228 citizens living. After the establishment of the power of Kingdom SHS, the first census was conducted in 1921. According to these data, in the Bregalnica district, which kept its borders from 1913, there were 104.347 citizens living. The published data from the census in 1921, being so detailed, help in the comparison analyzing of the structure of the population on the territory of Macedonia which was under the power of $K S H S$ regarding the period from the last decade from the Ottoman ruling, as well as during the Balkan wars and the First World War.

Keywords: BREGALNICA (ŠTIP) DISTRICT; ETHNO-DEMOGRAPHIC CHANGES; CENSUS OF POPULATION 